\title{
HUBUNGAN ANTARA MINAT BELAJAR DENGAN PRESTASI BELAJAR TERHADAP MATA PELAJARAN BAHASA INDONESIA SISWA KELAS IV
}

\author{
Haswinda, Sulfasyah, Tasrif akib \\ Pendidikan Guru Sekolah Dasar, Fakultas Keguruan dan Ilmu Pendidikan \\ Universitas Muhammadiyah Makassar \\ Iqramsyar34@gmail.com
}

\begin{abstract}
ABSTRAK
Desain penelitian ini adalah penelitian Korelasi Product Moment yang melibatkan dua variabel. Penelitian ini bertujuan untuk mengetahui(1) Minat belajar Siswa Terhadap Mata Pelajaran Bahasa Indonesia SDN 253 Padatuo Kecamatan Tonra Kabupaten Bone, (2) Prestasi Belajar Siswa Terhadap Mata Pelajaran Bahasa Indonesia SDN 253 Padatuo Kecamatan Tonra Kabupaten Bone, (3) Hubungan Antara Minat Belajar dengan Prestasi Belajar Terhadap Mata Pelajaran Bahasa Indonesia Siswa Kelas IV SDN 253 Padatuo Kecamatan Tonra Kabupaten Bone.

Populasi penelitian ini adalah seluruh siswa SDN 253 Padatuo Kecamatan Tonra Kabupaten Bone pada semester ganjil 2016/2017. Hasil analisis data memperlihatkan bahwa dari 30 siswa yang menjadi sampel penelitian, maka diperoleh nilai $r_{\text {hitung }}$ sebesar $\mathbf{0 , 5 3 1}$. Dari nilai $r_{\text {hitung }}$ yang diperoleh merupakan hasil dari analisis melalui product moment yang diambil dari pengamatan Hubungan Antara Minat Belajar dengan Prestasi Belajar Terhadap Mata Pelajaran Bahasa Indonesia Siswa Kelas IV SDN 253 Padatuo Kecamatan Tonra Kabupaten Bone, sedangkan nilai $r_{\text {tabel }}$ dilihat pada taraf signifikan $5 \%$ sebesar 0,361 dengan $\mathrm{N}=30$.

Hal ini membuktikan bahwa nilai analisis data lebih besar dari pada nilai $r_{\text {tabel, }}$ maka hipotesis yang diajukan dalam penelitian ini diterima dan terdapat hubungan yang signifikan antara minat belajar dengan prestasi belajar Terhadap siswa kelas IV SDN 253 Padatuo kecamatan tonra Kabupaten Bone
\end{abstract}

Kata Kunci :Minat belajar, Prestasi belajar Siswa pada Mata Pelajaran Bahasa indonesia. 


\section{PENDAHULUAN}

Sudah di sadari baik oleh guru, siswa dan orangtua bahwa dalam belajar disekolah intelegensi (kemampuan intelektual) memerankan peranan yang penting, khususnya berpengaruh kuat terharap tinggi rendahnya prestasi belajar siswa. Ini bermakna, semakin tinggi kemampuan intelegensi seorang siswa, maka semakin besar peluangnya untuk berprestasi. Sebaliknya, semakin rendah kemampuan intelegensi seorang siswa, maka semakin kecil peluangnya untuk memperoleh prestasi.

Dalam hal ini Minat merupakan landasan penting bagi seseorang untuk melakukan kegiatan dengan baik sebagai suatu aspek kejiwaan minat bukan saja dalam mempengaruhi tingkah laku seseorang, tapi juga mendorong orang untuk tetap melakukan dan memperoleh sesuatu. Hal itu sejalan dikatakan oleh S. Nasution (2010) bahwa pelajaran akan berjalan lancar apabila ada minat. Anakanak malas, tidak belajar, gagal karena tidak ada minat.

Dalam kegiatan belajar, minat mempunyai peranan yang sangat penting bila seorang siswa tidak memiliki minat dan perhatian yang besar terhadap objek yang dipelajari maka sulit diharapkan siswa tersebut akan tekun memperoleh hasil yang baik dari belajarnya, sebaliknya, apabila siswa tersebut belajar dengan minat perhatian besar terhadap objek yang dipelajari, maka hasil yang diperoleh lebih baik. Seperti yang diungkapkan oleh Usman Efendi dan Juhaya S Praja bahwa "Belajar dengan minat akan lebih baik daripada belajar tanpa minat". Dari keterangan diatas, dapat dijelaskan bahwa siswa yang memiliki minat dengan siswa yang tidak memiliki minat dalam belajar akan terdapat perbedaan. Perbedaan tersebut tampak jelas dengan ketekunan yang terus menerus. Siswa yang memiliki minat maka ia akan terus tekun ketika belajar. Sedangkan siswa yang tidak memiliki minat walaupun ia mau untuk belajar akan tetapi ia tidak terus untuk tekun untuk belajar.

Begitu pula dalam proses belajar dalam mata pelajaran Bahasa Indonesia tinggi rendahnya minat belajar siswa dalam mata pelajaran Bahasa Indonesia tentunya akan memberikan pengaruh terhadap prestasi belajar yang akan dicapai oleh siswa. Mata pelajaran Bahasa dan Sastra Indonesia di sekolah merupakan suatu pengembangan pengetahuan, keterampilan berbahasa , dan sikap positif terhadap Bahasa Indonesia. Bahasa Indonesia sebagai 
salah satu mata pelajaran di sekolah di nilai memegang peranan penting dalam membentuk siswa menjadi berkualitas, karena Bahasa Indonesia merupakan suatu sarana berpikir untuk mengkaji sesuatu secara logis, kritis, rasional dan sistematis serta melatih kemampuan peserta didik agar terbiasa dalam menyelasaikan suatu masalah yang ada di sekitarnya sehingga dapat mengembangkan potensi diri dan sumber daya yang dimiliki peserta didik. Salah satu faktor yang mempengaruhi prestasi belajar siswa adalah minat belajar siswa.

Berdasarkan observasi awal di SDN 253 Padatuo Kec. Tonra Kab. Bone, sebagian dari siswa ada yang mengaku senang dengan pelajaran Bahasa Indonesia dan sebagian siswa mengaku tidak senang dengan pelajaran Bahasa Indonesia. Tidak jarang siswa yang memandang Bahasa Indonesia sebagai mata pelajaran yang sulit, bahkan ada siswa yang menganggap bahwa Bahasa Indonesia adalah kegiatan pembelajaran yang membosankan. Fenomena yang terjadi di Kecamatan Tonra Kabupaten Bone, pada umumnya minat belajar siswa masih sangat kurang sehingga banyak siswa yang tidak mencapai hasil belajar yang maksimal, bahkan banyak diantara mereka putus sekolah karena kurangnya minat belajar pada diri mereka sendiri.

Berdasarkan uraian di atas rumusan masalah dalam penelitian ini adalah "Apakah terdapat hubungan antara minat belajar dengan prestasi belajar terhadap Mata Pelajaran Bahasa Indonesia Siswa Kelas IV SDN 253 Padatuo Kecamatan Tonra Kabupaten Bone ?". Untuk mengetahui hubungan antara minat belajar dengan prestasi belajar terhadap Mata Pelajaran Bahasa Indonesia Siswa Kelas IV SDN 253 Padatuo Kecamatan Tonra Kabupaten Bone.

\section{Minat Belajar}

Menurut Syah (2011:152), minat merupakan kecendurungan dan kegairahan yang tinggi atau keinginan untuk yang besar terhadap sesuatu. Sementara ituSlameto (2010:180) mengatakan bahwa minat adalah suatu hal atau aktivitas tanpa ada yang menyeluruh.Berdasarkan pengertian tersebut dapat disimpulkan bahwa minat akan timbul apabila mendapat rangsangan dari luar. Sehingga cenderung untuk merasa tertarik pada suatu bidang bersifat menetap dan merasakan perasaan yang senang apabila ia terlibat aktif didalamnya. Meskipun perasaan senang ini timbul 
dari lingkungan atau berasal dari objek yang menarik.

\section{Menurut Slameto (20010:2)} belajar ialah suatu proses usaha yang dilakukan seseorang untuk memperoleh suatu perubahan tingkah laku yang baru secara keseluruhan, sebagai hasil pengalamannya sendiri dalam interaksi dengan lingkungannya. Sedangkan menurut Suyono dan Harianto (2012:9) belajar adalah suatu aktivitas atau suatu proses untuk memperoleh pengetahuan, peningkatan, keterampilan, memperbaiki perilaku, sikap, dan mengkokohkan kepribadian. Berdasarkan kesimpulan diatas bahwa minat belajar adalah rasa tertarik atau kecenderungan melakukan 5 kegiatan untuk memperoleh pengetahuan atau perubahan perilaku sebagai hasil pengalamannya sendiri dalam interaksi dengan lingkungannya.

Dari beberapa gambaran definisi minat diatas, kiranya dapat ditegaskan di sini bahwa minat merupakan dorongan dalam diri seseorang atau faktor yang menimbulkan ketertarikan atau perhatian secara efektif, yang menyebabkan dipilihnya suatu objek atau kegiatan yang menguntungkan, menyenangkan, dan lama- kelamaan akan mendatangkan kepuasan pada dirinya.

\section{Prestasi Belajar}

Kata "prestasi" berasal dari bahasa Belanda yaitu prestatie. Kemudian dalam bahasa Indonesia menjadi prestasi yang berarti hasil usaha. Kata prestasi banyak digunakan dalam berbagai bidang dan kegiatan, antara lain dalam kesenian, olahraga dan pendidikan khususnya pengajaran. Misalnya si Ahmad mendapat juara satu dalam bidang seni suara, kemudian si Anwar menjadap juara umum dalam lari 1000 meter. Dari contoh ini dapat kita lihat bahwa prestasi yang dimkasud tidak lain adalah kemampuan, keterampilan dan sikap seseorang dalam menyelesaikan dalam suatu hal. Dalam tulisan ini, prestasi hanya dibatasi dalam bidang pendidikan khsuusnya pengajaran.

Prestasi belajar merupakan suatu masalah yang bersifat penting dalam sejarah kehidupan manusia karena sepanjang rentang kehidupannya manusia selalu mengejar prestasi menurut bidang dan kemampuan masing-masing. Bila demikian halnya, kehadiran prestasi belajar dalam kehidupan manusia pada tingkat dan jenis tertentu dapat memberikan kepuasan tertentu pula pada manusia, khususnya manusia yang berada pada bangku sekolah. 
Poerwanto (1986:28) memberikan pengertian prestasi belajar yaitu "hasil yang dicapai oleh seseorang dalam usaha belajar."

Selanjutnya Winkel (1996:162) mengatakan bahwa "prestasi belajar adalah suatu bukti keberhasilan belajar atau kemampuan seseorang siswa dalam melakukan kegiatan belajarnya sesuai dengan bobot yang dicapainya." Sedangkan menurut S. Nasution (1996:17) prestasi belajar adalah: "Kesempurnaan yang dicapai seseorang dalam berfikir, merasa dan berbuat. Prestasi belajar dikatakan sempurna apabila memenuhi tiga aspek yakni: kognitif, affektif dan psikomotor, sebaliknya dikatakan prestasi kurang memuaskan jika seseorang belum mampu memenuhi target dalam ketiga kriteria tersebut."

Berdasarkan pengertian di atas, maka dapat dijelaskan bahwa prestasi belajar merupakan tingkat kemanusiaan yang dimiliki siswa dalam menerima, menolak dan menilai informasiinformasi yang diperoleh dalam proses belajar mengajar.

\section{METODE PENELITIAN}

Data dalam penelitian ini ada dua variabel yaitu, minat belajar (X) dan prestasi belajar bahasa Indonesia (Y) diperoleh pada siswa Kelas IV SDN 253 Padatuo Kecamatan Tonra Kabupaten Bone dengan jumlah siswa kelas IV 30 orang. Data dua variabel tersebut diperoleh dari pembagian kuesioner (angket) dan dokumentasi.

Untuk menghitung korelasi product moment ini dilakukan dengan dua cara yaitu dengan cara manual dan di bantu dengan program SPSS 23.0 for Windows. Adapun dengan cara manual, penulis membuat tabel-tabel penolong untuk memudahkan dalam menghitung

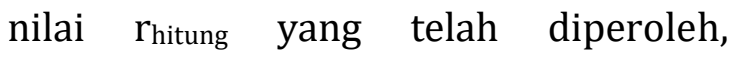
kemudian di konsultasikan dengan nilai $\mathrm{r}_{\text {tabel }}$ product moment. Adapun data yang di analisis adalah minat belajar (X) dan presatasi belajar bahasa Indonesia (Y)

\section{Variabel minat belajar bahasa Indonesia.}

Berikut ini akan penulis sajikan tabel distribusi skor minat belajar dari penyebaran angket tentang minat belajar bahasa Indonesia siswa Kelas IV SDN 253 Padatuo Kecamatan Tonra Kabupaten Bone.

Tabel 1 Distribusi Skor Minat belajar

\begin{tabular}{|l|l|l|l|l|}
\hline No & Skor & Frekuensi & $\begin{array}{c}\text { Persentase } \\
\%\end{array}$ & \multicolumn{1}{|c|}{ Kategori } \\
\hline 1 & $85-100$ & 10 & 33,33 & Sangat tinggi \\
\hline 2 & $67-84$ & 16 & 53,33 & Tinggi \\
\hline
\end{tabular}




\begin{tabular}{|l|l|l|l|l|}
\hline 3 & $51-66$ & 4 & 13,33 & Sedang \\
\hline 4 & $35-50$ & 0 & 0 & Rendah \\
\hline 5 & $0-34$ & 0 & 0 & Sangat rendah \\
\hline Jumlah & 30 & 100 & \\
\hline \multicolumn{4}{|l|}{ Mean Std.deviasi } \\
Minimum & \multicolumn{2}{|c|}{ Maksimum } \\
\hline $\begin{array}{l}80,00 \\
100\end{array}$ & & \\
10,505 &
\end{tabular}

Tabel 1 menunjukkan bahwa rata- rata skor minat belajar adalah 80,00 dan standar deviasi 10,505 dari skor ideal 100, skor minumum 60 dan skor maksimum 100 yang berarti minat belajar siswa berada dalam kategori sangat tinggi.

Tabel 1 pula diketahui bahwa 10 0rang yang berada dalam kategori sangat tinggi, 16 orang yang berada dikategori tinggi, 4 orang berada dikategori sendang, dan tidak ada yang berada pada kategori rendah dan sangat rendah. Sehingga frekuensi terbanyak berada di kategori tinggi dan frekuensi terendah berada di kategori sedang.

Namun secara keseluruhan, berdasarkan data tersebut dapat disimpulkan bahwa minat belajar siswa dalam kategori tinggi, hal ini sesuai dengan hasil observasi yang dilakukan oleh peneliti selama proses penelitian

\section{Variabel Prestasi Belajar Bahasa Indonesia.}

Berdasarkan hasil data keadaan nilai siswa pada mata pelajaran bahasa
Indonesia dengan 30 orang siswa yang dianalisis diperoleh gambaran yaitu tidak ada siswa yang memperoleh nilai 100 sebagai nilai maksimal.

Tabel 2 Distribusi Skor Prestasi belajar Bahasa Indonesia

\begin{tabular}{|c|c|c|c|c|}
\hline No & Skor & Frekuensi & $\begin{array}{c}\text { Persentasi } \\
(\%)\end{array}$ & Kategori \\
\hline 1 & $\begin{array}{l}90- \\
100\end{array}$ & 10 & 33 & $\begin{array}{c}\text { Sangat } \\
\text { tinggi }\end{array}$ \\
\hline 2 & $\begin{array}{c}80- \\
89\end{array}$ & 7 & 23 & Tinggi \\
\hline 3 & $\begin{array}{c}65- \\
79\end{array}$ & 8 & 27 & Sedang \\
\hline 4 & $\begin{array}{c}55- \\
64\end{array}$ & 5 & 17 & Rendah \\
\hline 5 & $\begin{array}{l}0- \\
54\end{array}$ & 0 & 0 & $\begin{array}{l}\text { Sangat } \\
\text { rendah }\end{array}$ \\
\hline \multicolumn{3}{|c|}{ Jumlah } & 30 & 100 \\
\hline \multicolumn{2}{|c|}{$\begin{array}{l}\text { Mean } \\
\text { Maksimum }\end{array}$} & d.deviasi & Variansi & Minimum \\
\hline \multicolumn{2}{|l|}{$\begin{array}{l}77,3 \\
90\end{array}$} & 11,121 & 123,678 & 60 \\
\hline
\end{tabular}

Berdasarkan tabel 2 menunjukkan bahwa rata-rata nilai raport bahasa Indonesia adalah 77,33 dan standar deviasi 11, 121 dan skor ideal 100, skor minimum 60 dan skor maksimum 90.

Tabel 2 pula diketahui bahwa ada 10 orang siswa berada dalam kategori sangat tinggi, 7 siswa berada dalam kategori tinggi, 8 siswa berada dalam kategori sedang, 5 siswa dalam kategori 
rendah, dan tidak ada siswa yang mendapat nilai sangat rendah.

Berdasarkan data tersebut dapat disimpulkan bahwa secara keseluruan prestasi belajar siswa yang berada pada kategori sangat tinggi adalah hasil yang diperoleh siswa setelah mempelajari materi yang disajikan dalam proses belajar mengajar yang dilakukan oleh guru kelas selama satu semester.

\section{Korelasi Minat Belajar dengan Prestasi Belajar Bahasa Indonesia}

Berdasarkan nilai angket minat belajar dan prestasi belajar bahasa Indonesia dikorelasikan sehingga dapat diketahui yang diajukan di terima atau di tolak. Korelasi minat belajar dan prestasi belajar Indonesia menggunakan program SPSS 23.0 for windows. Adapun hasil penggunaan program SPSS 23.0 for windows sebagai berikut:

Tabel 3 Hasil Analisis SPSS 23.0

\section{for windows.}

\section{Correlations}

\begin{tabular}{|c|c|c|c|}
\hline & & Minat_belajar & prestasi_belajar \\
\hline $\begin{array}{l}\text { Minat_bela } \\
\text { jar }\end{array}$ & $\begin{array}{l}\text { Pearson } \\
\text { Correlati } \\
\text { on } \\
\text { Sig. (2- } \\
\text { tailed) } \\
\text { N }\end{array}$ & 30 & $\begin{array}{l}.531^{* *} \\
.003 \\
30\end{array}$ \\
\hline
\end{tabular}

\begin{tabular}{|ll|l|l|} 
prestasi_b & Pearson & \\
elajar & Correlati & $.531^{* *}$ & 1 \\
& on & \\
& Sig. (2- & & \\
& tailed) & .003 & \\
& $\mathrm{~N}$ & 30 & 30 \\
\hline
\end{tabular}

**. Correlation is significant at the 0.01 level (2-tailed).

Berdasarkan tabel 3 hasil analisis data hubungan minat belajar dengan prestasi belajar bahasa Indonesia memperlihatkan bahwa dari 30 jumlah siswa yang menjadi sampel penelitian, maka diperoleh nilai $r_{\text {hitung }}$ sebesar 0,531 .

Untuk mengetahui nilai pengujian hipotesis penelitian maka nilai rhitung dibandingkan dengan nilai $\mathrm{r}_{\text {tabel }}$ pada taraf signifikan 5\%, kriteria pengujian hipotesis adalah sebagai berikut:

1. Apabila nilai $\mathrm{r}_{\text {hitung }}$ lebih besar dari pada nilai $r_{\text {tabel }}$ maka hipotesis diterima.

2. Apabila nilai $\mathbf{r}_{\text {hitung }}$ lebih kecil dari pada $r_{\text {tabel }}$ maka hipotesis di tolak.

3. Nilai $r_{\text {tabel }}$ yang digunakan sebagai pembanding, yaitu diketahui dengan cara mencari nilai yang berada pada taraf signifikan $5 \%$ dari $\mathrm{N}=30$.

Berdasarkan hasil program SPSS 23.0 for windows yang memperoleh nilai rxy atau $r_{\text {hitung }}$ adalah $\mathbf{0 . 5 3 1}$, selanjutnya dibandingkan dengan $r_{\text {tabel }}$ yang 
tercantum pada tabel taraf signifikan $5 \%$ tabel taraf signifikan $5 \%=0.361$ sedangkan $r_{\text {hitung }}$ adalah $\mathbf{0 . 5 3 1}$. Ketentuan jika $r_{\text {hitung }}>r_{\text {tabel }}$ maka diterima sedangkan jika $r_{\text {hitung }}<r_{\text {tabel }}$ maka ditolak. Dari hasil tampak bahwa $\mathrm{r}_{\text {hitung }}$ lebih besar dari $\mathrm{r}_{\text {tabel }}$ atau dapat digambarkan pada taraf signifikan 5\% $(0,531>0,361)$. Hal ini membuktikan bahwa nilai analisis data lebih besar dari pada nilai $r_{\text {tabel }}$ maka hipotesis yang diajukan dalam penelitian ini diterima dan terdapat hubungan yang positif dan signifikan antara minat belajar dengan prestasi belajar bahasa Indonesia siswa. Menurut Syah (2011:152), minat merupakan kecendurungan dan kegairahan yang tinggi atau keinginan untuk yang besar terhadap sesuatu. Sementara ituSlameto (2010:180) mengatakan bahwa minat adalah suatu hal atau aktivitas tanpa ada yang menyeluruh.Berdasarkan pengertian tersebut dapat disimpulkan bahwa minat akan timbul apabila mendapat rangsangan dari luar

Pada bagian ini akan diuraikan hasil yang ditemukan dalam penelitian. Hasil yang dimaksud yaitu kesimpulan yang diambil berdasarkan data yang terkumpul dan analisis data yang telah dilakukan. Sampel dari penelitian ini adalah 30 siswa yang dimana proses penentuan sampel menggunakan simpel ramdom sampling. Model pengumpulan data dengan membagikan angket dengan skor makimal 100 dan pengambilan data dengan dokumentasi atau pengambilan data hasil rapor siswa. Hasil analisis data memperlihatkan bahwa dari 30 jumlah siswa yang menjadi sampel penelitian, maka diperoleh nilai $r_{\text {hitung }}$ sebesar 0,531 .

Untuk mengetahui nilai pengujian hipotesis penelitian maka nilai $r_{\text {hitung }}$ dibandingkan dengan nilai $r_{\text {tabel }}$ pada taraf signifikan 1\%, kriteria pengujian hipotesis adalah sebagai berikut:

1. Apabila nilai $r_{\text {hitung }}$ lebih besar dari pada nilai $r_{\text {tabel }}$ maka hipotesis diterima.

2. Apabila nilai $r_{\text {hitung }}$ lebih kecil dari pada $r_{\text {tabel }}$ maka hipotesis di tolak.

3. Nilai $r_{\text {tabel }}$ yang digunakan sebagai pembanding, yaitu diketahui dengan cara mencari nilai yang berada pada taraf signifikan $1 \%$ dari $\mathrm{N}=30$.

Berdasarkan perhitungan manual yang menggunakan rumus korelasi product moment, penulis juga menggunakan bantuan program SPSS 22.0 for windows yang memperoleh nilai rxy atau $\mathbf{r}_{\text {hitung }}$ adalah $\mathbf{0 . 6 8 8}$, selanjutnya dibandingkan dengan $r_{\text {tabel }}$ yang tercantum pada tabel taraf signifikan 
1\% namun terlebih dahulu mencari derajat kebebasan $\mathrm{db}$ atau dregroes of freedom (df) dengan menggunakan rumus sebagai berikut:

$\mathrm{Df}=\mathrm{N}-\mathrm{nr}$

\section{Keterangan:}

Df = Dregroes of Freedom

$\mathrm{N}$ = Banyaknya sampel

$\mathrm{nr}=$ Banyaknya variabel

$\mathrm{Df}=\mathrm{N}-\mathrm{nr}$

$=30-2$

$=28$

Dengan mendapatkan nilai df-nya yaitu $\mathrm{df}=30-2=28$ maka dapat dilihat pada tabel nilai " $r$ " product moment (lampiran 6), pada tabel taraf signifikan $5 \%=0.361$ sedangkan $r_{\text {hitung }}$ adalah 0.531. Ketentuan jika $r_{\text {hitung }}>$ $r_{\text {tabel }}$ maka diterima sedangkan jika $r_{\text {hitung }}<r_{\text {tabel }}$ maka ditolak. Dari hasil tampak bahwa $r_{\text {hitung }}$ lebih besar dari $\mathrm{r}_{\text {tabel }}$ atau dapat digambarkan pada taraf signifikan $5 \%(\mathbf{0 , 5 3 1}>0,361)$. Hal ini membuktikan bahwa nilai analisis data lebih besar dari pada nilai $r_{\text {tabel }}$ maka hipotesis yang diajukan dalam penelitian ini diterima dan terdapat hubungan yang positif dan signifikan antara minat belajar dengan prestasi belajar bahasa Indonesia siswa.

Berdasarkan perhitungan dalam pengujian hipotesis ditemukan angka korelasi antara variabel x dan variabel y sebesar $\mathbf{0 . 5 3 1}$ itu berarti korelasi bertanda positif. Selanjutnya untuk melihat interpretasi terhadap angka indeks korelasi product moment secara sederhana dapat dilihat pada tabel 4.8 yang berada pada koefesien korelasi antara 0,40-0,599 dengan interpretasi yang dihasilkan termasuk dalam kategori sedang.

Berdasarkan penjelasan diatas dapat di simpulkan bahwa ada hubungan antara Minat Belajar dengan Prestasi belajar terhadap mata pelajaran Bahasa Indonesia Siswa Kelas IV SDN 253 Padatuo Kecamatan Tonra Kabupaten Bone.

\section{KESIMPULAN}

Berdasarkan analisis data dan hasil penelitian dan hasil pengujian hipotesis yang telah dilakukan, maka dapat ditarik kesimpulan sebagai berikut (1) Hubungan minat belajar dengan prestasi belajar terhadap mata pelajaran Bahasa Indonesia Siswa Kelas IV SDN 253 Padatuo Kecamatan Tonra Kabupaten Bone ditunjukkan oleh hasil dari penelitian, dengan perolehan nilai sebesar 99,6 \%. Berdasarkan angka yang didapat menunjukkan bahwa ada hubungan antara minat dengan prestasi belajar bahasa Indonesia. (2) Terdapat hubungan yang positif minat dengan 
prestasi belajar bahasa Indonesia yang ditunjukkan oleh hasil perhitungan dari koefisien korelasi (r) yaitu 0,531. berarti korelasi positif antara variabel X dan variabel $Y$ termasuk korelasi sangan tinggi ( sangat signifikan ). (3) Berdasarkan nilai $\mathrm{n}$ pada tabel taraf signifikan $5 \% \quad(0,361)$ dan taraf signifikan $1 \%=0,463$, dari nilai product moment ( tabel standar nilai product moment dilampirkan), maka hasil penelitian ini diterima baik taraf signifikan 5\% maupun 1\%.

Berdasarkan hasil penelitian, maka implikasi dari kesimpulan tersebut dikemukakan saran sebagai berikut (1) Bagi guru, hendaknya mampu memupuk dan mengembangkan minat belajar siswa untuk belajar bahasa Indonesia sehingga minat siswa dapat ditingkatkan ke arah yang lebih baik lagi. (2) Diharapkan kepada siswa agar dapat mengembangkan minat belajar yang dimiliki sehingga dapat memperoleh prestasi yang lebih baik. (3) Bagi peneliti selanjutnya, disarankan untuk meneliti variabelvariabel lain yang mempengaruhi prestasi belajar bahasa Indonesia seperti fasilitas belajar, ruang belajar, gaya belajar dan lain-lain.

\section{DAFTAR PUSTAKA}

Abdullah, Ambo Enre. 1985. Prinsipprinsip Layanan Bimbingan Belajar. FIP.IKIP Ujung Pandang.

Abdulrahman H. Moslow 1984. Fungsi prestasi belajar. Jakarta; Rineka Cipta

Arikunto Suharmini. 1990. Prestasi Belajar. Jakarta ; Bumi Aksara

Abdul Haling, dkk. Belajar dan Pembelajaran. Makassar: Badan Penerbit UNM

Arifin, 2012. Minat Belajar (online), No. 1 http://putraews.blogspot.co.id/2 012/06/minatbelajar,(diakses17 Mei 2016)

Ahmadi,H.Abu. 1990. Teknik Belajar Yang Efektif.Jakarta: RinekaCipta

AinulFadilah, 2014. PrinsipPrinsipBelajar. (online), No. 1

http://ainulfadilah.blogspot.co.id /2014/02/normal-0-false-falsefalse-en-us-x-none 7517.html, (diakses 13 Mei 2016)..

Anas, Sudijono. 1987. Pengantar Statistik Pendidikan. Jakarta: CV Rajawali.

Arikunto, Suharsimi. 1990. Manajemen Penelitian. Rineka Cipta.

Badudu, J.S. 1993. Pintar Berbahasa Indonesia.Jakarta: Depdikbud. 
1988. Kamus Besar Bahasa Indonesia.

Depertemen

Pendidikan

Nasional.Kurikulum(2004:3).Stan

darKompetensi

Mata

PelajaranKelas

IV

SekolahDasardan

Madrasah

Ibtidaiyah :Jakarta.

Departemen Agama. 2004. Standar

Kompetensi Madrasah Ibtidaiyah.

Jakarta:

Direktorat Jenderal Kelembagaan Islam.

Dimyati,Mudjiono.1999. Belajar dan Pembelajaran .Jakarta: Rineka Cipta.

Elizabeth Hurlock. 1990. ciri-ciri minat belajar. Jakarta; Bumi Aksara

Gagne, 1985. Prestasi belajar, Jakarta; Rineka Cipta

Hasnia yunita. 2009.Hubungan minat belajar dengan prestasi belajar Bahasa Indonesia Siswa kelas V $S D$ inpres parang loe kabupaten Gowa. Fakultas Bahasa dan Sastra Indonesia. Universitas Muhammadiyah Makassar.

Keraf, Gorys.1979. Komposisi Bahasa Indonesia.Jakarta: Nusa Indah.

Liang Gie, The.1979. Cara Belajar Yang Efesien.Jokjakarta: Gajah Mada University Press.
Mappa, Syamsu.

1977.

ApresiasiPendidikanLingkunganS

osialdanPrestasiBelajar,

Desertasi.

Makassar:

FakultasPascasarjana

IKIP

Makassar.

Nurgiyantoro, Burhan. 1988. Penilaian dalam Pengajaran Bahasa dan Sastra Indonesia. Jokjakarta: Gramedia.

Nasution. 2010. Minat belajar, Jakarta: Bumi Aksara

Rahmiaty. 2010. Korelasi minat belajar dengan prestasi belajar siswa kelas VI SD inpres 3/77 ujung lamuru kecamatan lappariaja kabupaten bone. Fakultas Ilmu Pendidikan Universitas Negeri Makassar

Sardiman,A.M. 2001. Interaksi dan Motivasi Belajar Mengajar. Jakarta: Raja Grafindo Persada.

Slamet. 1988. Belajar dan faktor-faktor yang Mempengaruhinya. Jakarta: Bina Aksara.

Syah. 2011. Pengertian minat belajar. Jakarta; Bumi Aksara

Subroto, Edi. Murtono,Sri. 1995. Bahasa Indonesia. Surakarta: PT.Pabela. 
Sutisna. 2012. Faktor-faktor yang mempengaruhi Prestasi Belajar. [online]. Tersedia Http:// Sutisna. Com/Artikel/Artikelkependidikan faktor-faktor yang mempengaruhi -Prestasi belajar(di akses tanggal 29 april 2016)

Tim Penyusun FKIP Unismuh Makassar. 2014. Pedoman Penulisan Skripsi. Makassar: Panrita Press Unismuh Makassar.

Tim Penyusun Kamus Pusat Bahasa, 2003. Kamus Besar Bahasa Indonesia Ed.3. Jakarta: Balai Pustaka. 